ISSN $1507-3858$

e-ISSN 2450-0003

\title{
Iwona Chomiak-Orsa
}

Uniwersytet Ekonomiczny we Wrocławiu

e-mail: iwona.chomiak@ue.wroc.pl

ORCID: 0000-0003-3550-8624

\section{Katarzyna Golusińska}

Wyższa Szkoła Logistyki w Poznaniu

ORCID: 0000-0003-3354-1631

\section{Jakub Kruczek}

Wyższa Szkoła Logistyki w Poznaniu

ORCID: 0000-0002-6158-3444

\section{Andrzej Chluski}

Politechnika Częstochowska

ORCID: 0000-0002-0586-6060

\section{WYKORZYSTANIE NOWOCZESNYCH \\ TECHNIK NAUCZANIA W KREOWANIU \\ KOMPETENCJI MIĘKKICH}

\section{THE IMPLEMENTATION OF MODERN TEACHING METHODS IN THE SOFT SKILS CREATION}

DOI: $10.15611 /$ ie.2018.3.02

JEL Classification: A20, A29, I23

Streszczenie: Celem artykułu jest wskazanie możliwości wykorzystania nowoczesnych technik nauczania w kreowaniu kompetencji miękkich. Duża ewolucyjność i elastyczność organizacji oraz zmieniające się formy zatrudniania istotnie wpływają na oczekiwania pracodawców w obszarze umiejętności oraz kompetencji pracowników. Determinuje to konieczność zmian w procesach dydaktycznych, które powinny nie tylko umożliwiać wykształcenie specjalistów w określonej branży, ale również rozwijać cechy i umiejętności miękkie. Artykuł jest konsekwencją badań prowadzonych w ramach projektu pt.: The Acceleration Method of Development of Transversal Competences in the Students' Practical Training Proces, zrealizowanego w ramach finansowania z program Erasmus + .

Słowa kluczowe: metody dydaktyczne, warsztat dydaktyczny, model kompetencji, kompetencje miękkie. 
Summary: The aim of the article is an indication of the possibilities of using modern teaching techniques in the creation of competence. The high evolutionary aspect and the flexibility of the Organization and the changing forms of employment significantly affect employers' expectations in the area of skills and competence of the employees. It determines the need for changes in the educational processes, which should enable the education of not only specialists in a specific industry but also develop features and soft skills. The article is a consequence of the research carried out within the framework of the project entitled: The Acceleration Method of Development of Transversal Competences in the Students 'Practical Training Process, realized within the framework of the financing of the Erasmus+ programme.

Keywords: teaching methods, didactic workshop, competency model, soft competencies.

\section{Wstęp}

Proces kształcenia jest jednym z najważniejszych etapów każdego człowieka. Oczywiście model doskonalenia zawodowego oraz rozwijania wiedzy branżowej i umiejętności zawodowych przez całe życie staje się koniecznością wobec zmienności oczekiwań pracodawców. Coraz większego znaczenia nabierają zatem narzędzia i procesy umożliwiające rozwój zawodowy realizowany w trakcie całego życia zawodowego. W tym kontekście niezbędne jest wprowadzanie zmian w procesach edukacyjnych oraz dydaktycznych. Procesy te powinny odpowiadać potrzebom słuchaczy, umożliwiać im zdobywanie aktualnej wiedzy branżowej i rozwijanie kompetencji miękkich, które wspomagają pracę zespołową i kreatywność jednostki.

Celem artykułu jest wskazanie na główne determinanty doskonalenia procesu dydaktycznego oraz omówienie możliwości wykorzystania nowoczesnych technik nauczania w szkolnictwie wyższym. Dlatego też autorzy, wychodząc od modelu kompetencji, zwrócili uwagę na przesłanki doskonalenia procesów dydaktycznych. Jako jeden z kierunków transformacji procesów dydaktycznych wskazano nowoczesne techniki nauczania, które przyczyniają się do inicjowania oraz rozwijania kompetencji miękkich.

Artykuł stanowi rezultat badań prowadzonych w ramach projektu Erazmus+ pt.: The Acceleration Method of Development of Transversal Competences in the Students' Practical Training Proces. Zaprezentowane w tekście rozważania mają charakter badań literaturowych, wynikają także z dokonanych badań empirycznych ${ }^{1}$, mających na celu zidentyfikowanie stanu wykorzystania nowoczesnych technik nauczania w procesach dydaktycznych na poziomie szkolnictwa wyższego.

Autorzy podjęli próbę klasyfikacji nowoczesnych technik nauczania oraz przyporządkowania ich do inspirowania i pobudzania określonych kompetencji miękkich.

${ }^{1}$ Wybrane aspekty prowadzonych badań $\mathrm{w}$ przytoczonym projekcie zaprezentowano $\mathrm{w}$ takich opracowaniach, jak: [Chomiak-Orsa 2017, s. 102-121; Jelonek, Chomiak-Orsa 2018]. 


\section{Znaczenie kompetencji miękkich w dobie pracowników wiedzy}

Potoczne rozumienie kompetencji różni się niejednokrotnie od perspektyw definicyjnych, które można znaleźć w literaturze. Co więcej, analiza literatury wskazuje na mnogość definicji [Dubois, Rothwell 2008, s. 32; Armstrong 2006, s. 161; Syper-Jędrzejak 2014, s. 433; Walkowiak 2007, s. 68-70; Lewicka 2010, s. 78-80; Tyrańska 2012, s. 56-58, Mikuła 2006, s. 210], która przyczynia się do niejednoznaczności interpretacyjnej, jak również tworzenia różnorodnych modeli kompetencji [Bartkowiak 2011, s. 133-134; Jędrzejczyk 2013, s. 87; Bratnicki 2000, s. 16-17].

Przyjmując zstępujący model kompetencji, można dokonać podziału kompetencji ze względu na zakres zadań, które są im przypisywane. W tym ujęciu kompetencje można podzielić na trzy poziomy przyporządkowania (por. rys. 1).

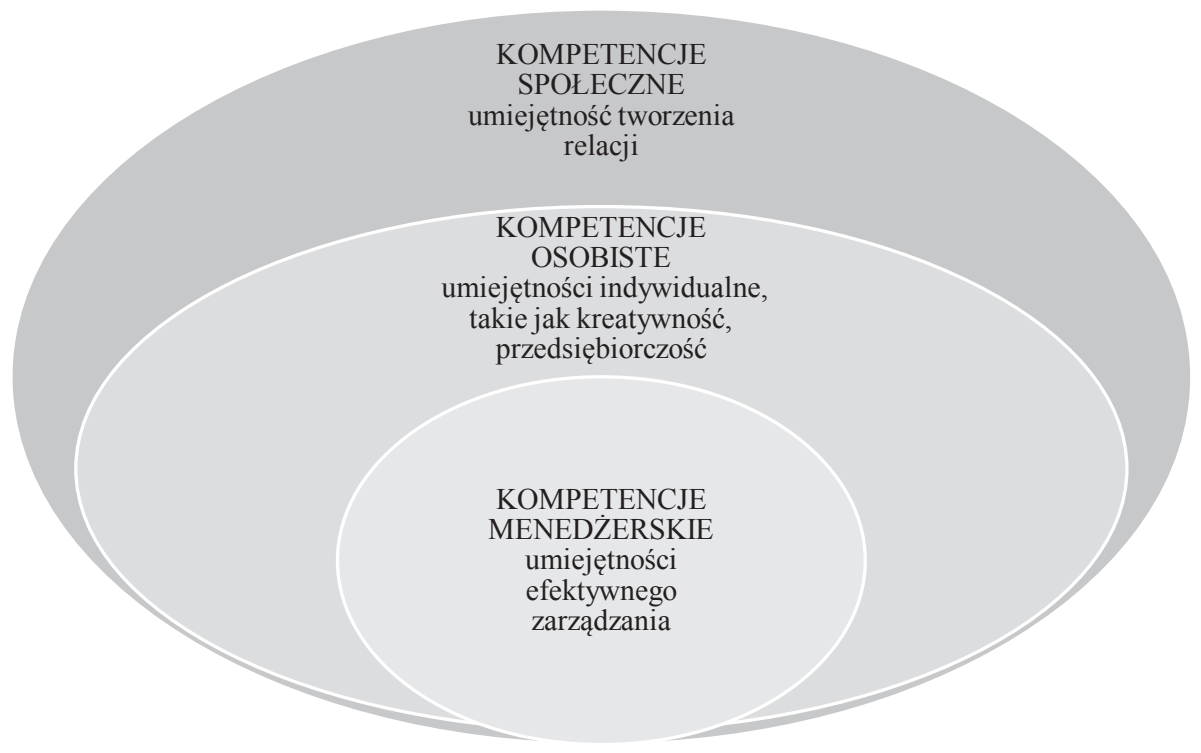

Rys. 1. Perspektywy kompetencji ze względu na zakres zadań

Źródło: opracowanie własne na podstawie [Rzempała 2017, s. 417-422; Siwak 2014, s. 41-54].

Odchodzenie od przetwarzania zasobów materialnych oraz dążenie do wytwarzania dóbr wiedzy i zaspokajania potrzeb niematerialnych w istotny sposób zwiększyły znaczenie umiejętności miękkich, takich jak przedsiębiorczość, kreatywne, abstrakcyjne myślenie, komunikacja czy umiejętność pracy w grupie. Dlatego też w dobie pracowników wiedzy kompetencje miękkie stają się dla pracodawców kluczową cechą pracowników. Realizując procesy dydaktyczne, coraz większy nacisk kładzie się zatem na pobudzanie w przyszłych pracownikach oraz doskonalenie wymienionych umiejętności. 
Analizując zakres kompetencji w ujęciu zaprezentowanych na rys. 1 trzech perspektyw oddziaływania, zauważyć można szczególną wagę kompetencji umożliwiających kreowanie, nawiązywanie oraz budowanie relacji. Te szczególne umiejętności pozwalają na skuteczne funkcjonowanie pracowników w sieciach organizacyjnych. W drugiej perspektywie umieszczone zostały kompetencje, takie jak kreatywność oraz abstrakcyjne myślenie. Niemniej znajdują się one w czołówce umiejętności oczekiwanych przez menedżerów oraz właścicieli współczesnych organizacji [Nawrat 2013, s. 32-33]. Wraz ze zwiększaniem się liczby zawodów, w których umiejętności miękkie stają się kluczowe, silniejsze staje się dążenie do lepszego dostosowania się do potrzeb organizacji. To z kolei determinuje większe możliwości awansu oraz rozwoju osobistego [Rosiński 2015, s. 217-228].

Aktualnie absolwenci uczelni wyższych zajmują stanowiska menedżerów bądź specjalistów. Mogą także dążyć do wypracowania sobie marki w zawodzie, która umożliwi im podejmowanie pracy jako tzw. freelancer.

Lista zawodów, które można wykonywać w sposób zdalny, w tzw. wirtualnych zespołach, wzrasta. Paradoksalnie wykorzystanie Internetu oraz komunikacji zdalnej zwiększa zapotrzebowanie na umiejętności miękkie pracowników. Praca w zespołach wirtualnych i na zasadzie wolnych specjalistów zatrudnianych incydentalnie do pracy nad wybranymi projektami z jednej strony zwiększa stres, jakiemu poddawany jest pracownik, a z drugiej jest bardziej wymagająca w kontekście umiejętności kreacji pewnych rozwiązań, abstrakcyjnego bądź analitycznego myślenia czy umiejętności skutecznego komunikowania się w eventowym zespole projektowym.

Ewolucja rynku pracy i warunków pracy determinuje konieczność zmian w stosowanych technikach nauczania oraz warsztacie dydaktycznym wykorzystywanym na poszczególnych etapach procesów edukacyjnych. W związku z tym w procesach edukacyjnych coraz częściej wykorzystywane są nowatorskie techniki nauczania mające przyczynić się do zwiększenia umiejętności i kompetencji miękkich.

\section{Przegląd nowoczesnych technik nauczania stosowanych w szkolnictwie wyższym}

Przyjmując retrospektywną perspektywę analizy procesów edukacyjnych w szkolnictwie wyższym, możemy zidentyfikować kilka, kilkanaście pasywnych technik nauczania i bardzo nieliczną grupę aktywizujących technik nauczania, wśród których główne miejsce zajmowały praktyki zawodowe odbywane na uczelniach zawodowych bądź zajęcia laboratoryjne prowadzone na uczelniach technicznych. Bodźce napływające $\mathrm{z}$ otoczenia i brak doświadczenia praktycznego absolwentów zmusiły podmioty edukacyjne do wprowadzania zmian w warsztacie dydaktycznym. Aktualnie oferowane na uczelniach wyższych procesy i metody kształcenia muszą sprostać wymaganiom współczesnych przedsiębiorców. Ewoluujący rynek pracy determinuje poszukiwanie pracowników nie tylko cechujących się wiedzą z określonej dziedziny zawodowej, ale także mających bardzo rozwinięte umiejętności miękkie. 
W procesach edukacyjnych coraz częściej stosowane są zatem nowoczesne, interaktywne techniki nauczania, mające na celu zaktywizować odpowiednie umiejętności odpowiednio w perspektywie: społecznej, osobistej, menedżerskiej. Dlatego też w procesach dydaktycznych może być wykorzystywanych wiele technik nauczania, które powinny być stosowane adekwatnie do oczekiwanych rezultatów nauczania. W literaturze można spotkać się z podziałem technik nauczania na grupy w zależności od pożądanych efektów. Techniki te tworzą cztery grupy (rys. 2).

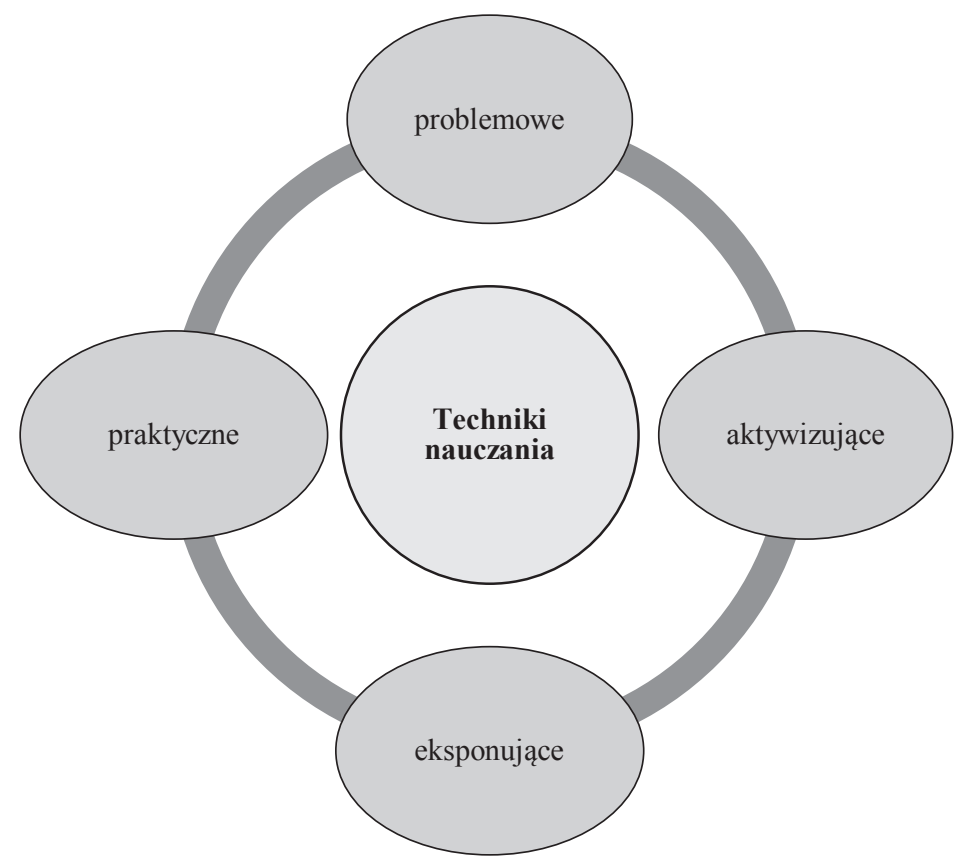

Rys. 2. Grupy technik nauczania

Źródło: opracowanie własne na podstawie [Chomiak-Orsa 2017, s. 102-121; The Report Concerning... 2016].

Techniki problemowe - mają za zadanie rozwijać umiejętności krytycznego myślenia. Ich ideą jest przedstawienie słuchaczom sytuacji problemowej oraz zorganizowanie im procesu poznawczego, który pobudzi i zainicjuje wykreowanie rozwiązań. W tych technikach wykorzystywane są różnorodne źródła informacji, np. filmy dydaktyczne, zestawienia danych liczbowych, prezentacja materiałów publikacyjnych czy literaturowych. Zakłada się, że w procesach dydaktycznych stosujących omawiane techniki nauczania procesy poznawcze będą składały się $\mathrm{z}$ takich etapów, jak: analizowanie materiałów, definiowanie problemów, wyjaśnianie, ocenianie, porównywanie problemów oraz poszukiwanie rozwiązań na zasadach m.in. benchmarkingu i wnioskowania. 
Techniki aktywizujące - ich zadaniem jest aktywizowanie uczestników procesu dydaktycznego do działania i samodzielnego podejmowania prób definiowania i rozwiazywania problemów. W tej grupie technik nauczania dąży się do uaktywnienia jednostki w grupie. Omawiane metody zakładają przede wszystkim zwiększenie czynnego udziału studentów w zajęciach dydaktycznych, ograniczając jednocześnie rolę wykładowcy do moderatora, mającego pełnić funkcje wspomagające i monitorujące realizację procesów, w których studenci samodzielnie wyznaczają działania niezbędne w osiąganiu celów edukacyjnych.

Techniki eksponujące [Bereźnicki 2001] - stanowią grupę technik wdrażających w procesy dydaktyczne nowoczesne podejście do sposobu nauczania, w którym uczący się ma nabywać umiejętności poprzez empatyzację. Mają one zwiększyć wartość wyrazu poprzez umożliwienie uczestnikom głębszego przeżywania określo-

Tabela 1. Typologia technik dydaktycznych oraz kompetencje, które kreują

\begin{tabular}{|c|c|c|}
\hline Grupa technik & Nazwa techniki dydaktycznej & $\begin{array}{l}\text { Rodzaj kreowanej } \\
\text { kompetencji }\end{array}$ \\
\hline Techniki problemowe & $\begin{array}{l}\text { - burza mózgów, } \\
\text { - obserwacja, } \\
\text { - dyskusja panelowa, } \\
\text { - } \text { studium przypadku (zob. [Jabłonowska } \\
\text { 2011, s. 81-99]) }\end{array}$ & $\begin{array}{l}\text { - myślenie analityczne, } \\
\text { - komunikacja }\end{array}$ \\
\hline Techniki aktywizujące & $\begin{array}{l}\text { - } \\
\text { - } \\
\text { - inscenize study, } \\
\text { - coaching (zob. [Brzeziński 2014, } \\
\text { s. 166-175; Szafran 2018, s. 37-54]), } \\
\text { - } \\
\text { naśladowanie społecznie kompetentnych } \\
\text { modeli, } \\
\text { - } \\
\text { - } \\
\text { learnenie się przez odkrywang by doing, } \\
\text { - } \\
\text { sześć kapeluszy de Bono (zob. [Rau, } \\
\text { Ziętkiewicz 2000]) }\end{array}$ & $\begin{array}{l}\text { - kreatywność } \\
\text { - myślenie analityczne, } \\
\text { - przedsiębiorczość, } \\
\text { - praca w grupie }\end{array}$ \\
\hline Techniki eksponujące & $\begin{array}{l}\text { - pokaz, } \\
\text { - psychodrama, } \\
\text { - design thinking, } \\
\text { - uczenie się refleksyjne, } \\
\text { - symulacyjne gry dydaktyczne }\end{array}$ & $\begin{array}{l}\text { - kreatywność } \\
\text { - myślenie analityczne, } \\
\text { - praca w grupie, } \\
\text { - przedsiębiorczość, } \\
\text { - komunikacyjność }\end{array}$ \\
\hline Techniki praktyczne & $\begin{array}{l}\text { - ćwiczenia przedmiotowe, } \\
\text { - ćwiczenia laboratoryjne, } \\
\text { - ćwiczenia produkcyjne, } \\
\text { - metoda projektowa, } \\
\text { - seminarium, } \\
\text { - symulacja }\end{array}$ & $\begin{aligned} \text { - } & \text { kreatywność, } \\
\text { - } & \text { przedsiębiorczość, } \\
& \text { myślenie analityczne }\end{aligned}$ \\
\hline
\end{tabular}

Źródło: opracowanie własne na podstawie [Chomiak-Orsa 2017, s. 102-121; The Report Concerning... 2016]. 
nych wartości, sytuacji kryzysowych, symulacji zdarzeń i problemów zachodzących w realnym świecie.

Techniki praktyczne [Petty 2010; Bereźnicki 2001] - w ich skład wchodzą najbardziej tradycyjne narzędzia dydaktyczne, stosowane przez wiele lat w dydaktyce zawodowej. Techniki te pozwalają na rozwinięcie umiejętności skutecznego działania, wdrażania teorii w praktykę oraz na zdobywanie nowych doświadczeń w działaniu, również w obszarze zarządzania zespołami.

Wymienione techniki mogą być łączone w dowolne modele nauczania, w zależności od tego, jakich efektów nauczania oczekujemy. W przypadku pobudzania oraz rozwijania umiejętności miękkich istotne są ciągłość stosowania wybranych technik dydaktycznych, jak również tworzenie modeli procesowych nauczania, w których szczególne miejsce zajmować powinny techniki aktywizujące.

W artykule autorzy wskazali na grupy wybranych technik nauczania oraz na zakres wspomagania przez te techniki przyrostu umiejętności i kompetencji miękkich.

\section{Podsumowanie}

Współczesne procesy dydaktyczne mogą wykorzystywać wiele technik dydaktycznych, których zadaniem jest nie tylko zwiększanie efektywności nauczania merytorycznego, ale również wspomaganie inicjowania i pobudzania umiejętności miękkich, takich jak: kreatywność, przedsiębiorczość, myślenie abstrakcyjne i analityczne, komunikatywność oraz umiejętność pracy w grupie.

Podstawą do napisania niniejszego artykułu były badania literaturowe i empiryczne wynikające z uczestnictwa jednego z autorów w projekcie pt.: The Acceleration $\mathrm{Me}$ thod of Development of Transversal Competences in the Students' Practical Training Proces, zrealizowanego w ramach finansowania z programu Erasmus+.

\section{Literatura}

Armstrong M., 2006, A Handbook of Human Resource Management Practice, wyd. 10, Kogan Page, London, Philadelphia.

Bartkowiak M., 2011, Kompetencje menedżera a relacje międzypracownicze w organizacji uczacej się, Wydawnictwo Naukowe UAM, Poznań.

Bereźnicki F., 2001, Dydaktyka ksztatcenia ogólnego, Kraków.

Bratnicki M., 2000, Kompetencje przedsiębiorstwa. Od określenia kompetencji do zbudowania strategii, Agencja Wydawnicza Placet, Warszawa.

Brzeziński Ł., 2014, Coaching - możliwość wykorzystania w edukacji, Przegląd Pedagogiczny, nr 2(25), s. 166-175.

Chomiak-Orsa I., 2017, Process Tools to Improve the Quality of Education in the Creation of Transversal Competence, [w:] The Acceleration of Development of Transversal Competences, red. Więcek-Janka E., Spychała M., Szafrański M., Goliński M, Centria University of Applied Sciences.

Dubois D.D., Rothwell W.J., 2008, Zarzadzanie zasobami ludzkimi oparte na kompetencjach, Wydawnictwo Helion, Gliwice. 
Jabłonowska L., 2011, Metoda przypadku w zapewnieniu jakości kształcenia menedżerów, Edukacja Ekonomistów i Menedżerów: Problemy, Innowacje, Projekty, nr 1(19).

Jędrzejczyk W., 2013, Intuicja jako kompetencja menedżerska $w$ teorii i praktyce zarządzania przedsiębiorstwem, TNOiK „Dom Organizatora”, Toruń.

Jelonek D., Chomiak-Orsa I., 2018, The Application of Modern Teaching Methods as the Development Determinant of Personal and Interpersonal Competences of Students-Future Employees, 10th International Conference on Education and New Learning Technologies, Palma, Spain, 2-4 July, 2018, ISBN: 978-84-09-02709-5, ISSN: 2340-1117.

Lewicka D., 2010, Zarządzanie kapitałem ludzkim w polskich przedsiębiorstwach, Wydawnictwo Naukowe PWN, Warszawa.

Mikuła B., 2006, Organizacje oparte na wiedzy, Wydawnictwo Akademii Ekonomicznej w Krakowie, Kraków.

Nawrat D., 2013, Ksztattowanie kompetencji innowacyjnych $w$ świetle badań biografii menedżerów, Przedsiębiorczość i Zarządzanie, t. 14, z. 4, Łódź.

Petty G., 2010, Nowoczesne nauczanie. Praktyczne wskazówki i techniki dla nauczycieli, wykładowców i szkoleniowców, Sopot.

Rau K., Ziętkiewicz E., 2000, Jak aktywizować uczniów. Burza mózgów i inne techniki w edukacji, Oficyna Wydawnicza G\&P, Poznań.

Rosiński J., 2015, The specificity of selected tools of development of social competencies among IT specialists, Jagiellonian Journal of Management, nr 3, t. 1.

Rzempała J., 2017, Kompetencje indywidualne i organizacyjne w zarzadzaniu projektami - ujęcie systemowe, Zeszyty Naukowe Politechniki Śląskiej, Organizacja i Zarządzanie, z. 114, nr kol. 1993, s. 417-422.

Siwak K., 2014, Wpływ kluczowych kompetencji na zdolność kreowania modeli biznesowych w przedsiębiorstwach, [w:] Przedsiębiorstwo we wspótczesnej gospodarce - teoria i praktyka, Quarterly Journal, nr 2, s. 41-54.

Syper-Jędrzejak M., 2014, Zarządzanie różnorodnościa jako istotna kompetencja współczesnego menedżera, Wydawnictwo Uniwersytetu Ekonomicznego we Wrocławiu, Wrocław.

Szafran J., 2018, Coaching jako specyficzna forma dialogu $i$ wsparcia wychowawczego, Kwartalnik Pedagogiczny, nr 2 (248/2018).

The Report Concerning Applied Teaching Methods of Transversal Skills and Methods of Practical Trainings, 2016, elaborated by Poznan University of Technology, Poznań.

Tyrańska M., 2012, Wspótczesne tendencje w zarządzaniu zasobami ludzkimi, Difin, Warszawa.

Walkowiak R., 2007, Zarzadzanie zasobami ludzkimi. Kompetencje. Nowe trendy. Efektywność, TNOiK „Dom Organizatora”, Toruń. 